\title{
Rheological effects of bed rest in sickle cell disease
}

\author{
A J KEIDAN, J STUART
}

From the Department of Haematology, The Medical School, University of Birmingham, Birmingham

SUMMARY A serial rheological study in two patients with homozygous sickle cell disease whose leg ulcers healed as a consequence of bed rest showed an improvement in erythrocyte deformability (filterability) associated with evidence of decreased haemolysis and a fall in the number of irreversibly sickled cells. This rheological improvement may aid the healing of leg ulcers by increasing blood flow in the ulcer base. The effects of bed rest on the rheology of sickle cell disease should be taken into account in future studies of vaso-occlusive crisis.

Leg ulceration is a well recognised complication of sickle cell disease (SCD) ${ }^{1}$ although the exact pathogenesis is uncertain and its management remains unsatisfactory. Bed rest can produce rapid healing, ${ }^{2}$ which, in part, may be due to the reduction in venous back pressure and in lymphoedema around the ankle. ${ }^{13}$ A study of the effect of bed rest on the rheology of SCD has not previously been reported. We therefore made a longitudinal study of the changes in the deformability of sickle cells in two patients during and after a period of strict bed rest for leg ulceration.

\section{Patients and methods}

\section{CASE 1}

A 20 year old man with homozygous SCD developed an ankle ulcer after minor injury. Daily dressings and oral zinc sulphate were unhelpful and the ulcer enlarged to $40 \mathrm{~mm}$ diameter over four months. After two weeks' strict bed rest the ulcer began to heal, with healthy granulation tissue forming at the edges and base. The patient was allowed to sit in a wheelchair provided that his leg was kept raised. After 28 days a support stocking was fitted and the patient resumed normal activities, resting his leg whenever possible. Four weeks later the ulcer had resolved completely.

\section{CASE 2}

An ulcer developed spontaneously on the left ankle of a 19 year old man with. homozygous SCD and impaired renal function (creatinine clearance 41 $\mathrm{ml} /$ minute). Despite local treatment and oral zinc sulphate the ulcer continued to enlarge. Five months later a second ulcer developed on the other ankle. Eleven days of strict bed rest were associated with healing of the ulcer on the left ankle and noticeable improvement of that on the right ankle. After three weeks' limited activity and keeping his leg raised the

Accepted for publication 22 April 1987 right ulcer also healed.

Haemoglobin concentration and red cell distribution width were measured using a Coulter S Plus IV electronic counter (Coulter Electronics Ltd, Luton). Reticulocytes were stained using $1 \% \mathrm{w} / \mathrm{v}$ New methylene blue and counted manually. ${ }^{4}$ Fully oxygenated blood was fixed using $1.25 \% \mathrm{w} / \mathrm{v}$ glutaraldehyde in phosphate buffered saline and the number of irreversibly sickled cells (ISC) determined using interference microscopy. 5 Total bilirubin was measured using an SMA 12/60 analyser (Technicon Ltd, Tarrytown, New York, USA).

Erythrocyte deformability was measured at $25^{\circ} \mathrm{C}$ using a pure suspension of erythrocytes in phosphate buffered saline (packed cell volume $=0.03$ ) prepared by prefiltration of whole blood through Imugard IG 500 cotton wool. ${ }^{6}$ An initial flow rate Hemorheometre was used to determine the index of filtration (IF) $^{7}$ through $5 \mu \mathrm{m}$ pore diameter polycarbonate filters (Nuclepore Corporation, Pleasanton, California, USA), an increase in IF indicating loss of erythrocyte deformability (filterability).

\section{Results}

After one week's strict bed rest, both patients showed an improvement in erythrocyte deformability (table), which continued while the patients' activity was restricted, but rose to the admission value, in case 1 , when normal activity was resumed. Over the same time course in this patient there was evidence of a decrease in the haemolytic rate, with a rise in haemoglobin concentration and fall in reticulocyte count and serum bilirubin concentration. The number of ISC and dense cells (estimated from the red cell distribution width ${ }^{8}$ ) also fell while activity was restricted.

An improvement in erythrocyte filterability associated with a fall in serum bilirubin concentration and ISCs following a period of strict bed rest also occurred in case 2. Failure to observe changes in 
Table 1 Haematological and rheological effects of bed rest in two patients with SCD

\begin{tabular}{|c|c|c|c|c|c|c|c|}
\hline & $\begin{array}{l}\text { Index of } \\
\text { filtration }\end{array}$ & $\begin{array}{l}\text { Haemoglobin } \\
\text { concentration } \\
\text { (g/dl) }\end{array}$ & $\begin{array}{l}\text { Reticulocytes } \\
\left(\times 10^{9} / l\right)\end{array}$ & $\begin{array}{l}\text { Bilirubin } \\
(\mu \mathrm{mol} / \mathrm{l})\end{array}$ & $\begin{array}{l}\text { Irreversibly } \\
\text { sickled cells } \\
\left(\times 10^{9} / l\right)\end{array}$ & $\begin{array}{l}\text { Red cell } \\
\text { distribution width } \\
(\%)\end{array}$ & Activity level \\
\hline \multicolumn{8}{|l|}{ Case 1} \\
\hline Day 0 & 89 & $6 \cdot 5$ & 616 & 90 & 761 & $27 \cdot 8$ & Admission \\
\hline Day 7 & 62 & $7 \cdot 4$ & 564 & 79 & 592 & $27 \cdot 0$ & Strict bed rest \\
\hline Day 16 & 41 & $7 \cdot 7$ & 545 & & 517 & $23 \cdot 1$ & Strict bed rest \\
\hline Day 22 & 51 & $7 \cdot 1$ & - & 62 & 473 & $25 \cdot 8$ & Wheelchair \\
\hline Day 28 & 48 & $7 \cdot 4$ & 340 & 87 & 470 & $24 \cdot 3$ & Wheelchair \\
\hline Day 39 & 84 & $6 \cdot 4$ & 741 & 91 & 642 & $27 \cdot 1$ & Normal activit \\
\hline \multicolumn{8}{|l|}{ Case 2} \\
\hline Day 0 & 80 & $5 \cdot 9$ & 234 & 48 & 530 & $22 \cdot 9$ & Admission \\
\hline Day 6 & 63 & $5 \cdot 7$ & 298 & 35 & 455 & $23 \cdot 3$ & Strict bed rest \\
\hline Day 11 & 59 & $5 \cdot 7$ & 428 & 41 & 444 & $23 \cdot 0$ & Strict bed rest \\
\hline Day 44 & - & $6 \cdot 2$ & 277 & 55 & - & - & Normal activity \\
\hline
\end{tabular}

haemoglobin concentration, reticulocyte count, or red cell distribution width may have been due to the patient's impaired marrow function secondary to chronic renal failure.

\section{Discussion}

In normal subjects prolonged bed rest decreases plasma volume ${ }^{9}$ which may, in part, explain the rise in haemoglobin concentration seen in case 1 . The fall in bilirubin concentration and reticulocyte count suggest, however, that a decrease in haemolytic rate may also have occurred, leading to a true increase in red cell mass. An increase in packed cell volume is known to have an adverse effect on the viscosity of whole blood $^{10}$ but, in the microcirculation, erythrocyte deformability is thought to be the main determinant of flow. ${ }^{11}$ Improved erythrocyte filterability (deformability) was observed in both patients following strict bed rest and was associated with a fall in ISCs and, in case 1 , in the population of dense cells. The mechanism of formation of ISC and dense cells is thought to be repetitive cycles of oxygenation and deoxygenation leading to cytoplasmic dehydration. ${ }^{12}$ Bed rest in normal subjects has haemodynamic and metabolic effects, ${ }^{9}$ and these changes may reduce the rate of formation of ISCs and other dense cells in SCD.

Reduction in local venous back pressure and lymphoedema provide an incomplete explanation for the healing of chronic leg ulcers in SCD following bed rest. ${ }^{1}$ We have now shown the additional factor of improved erythrocyte deformability. The resulting increase in blood flow in the ulcer base may explain the often rapid response to bed rest. Our results also suggest that caution is required in the interpretation of rheological changes during vaso-occlusive sickle cell crisis $^{13^{14}}$ as these patients are often bed-bound for several days.
We are indebted to the Action Research for the Crippled Child for a research training fellowship to AJK. We thank Dr IM Franklin for allowing us to study his patients and SS Marwah for technical assistance.

\section{References}

1 Serjeant GR. Leg ulceration. In: Sickle cell disease. Oxford: Oxford University Press, 1985:160-67.

2 Serjeant GR. Leg ulceration in sickle cell anemia. Arch Intern Med 1974;133:690-4.

3 Ryan TJ. The management of leg ulcers. Oxford: Oxford Univere sity Press, 1983.

4 Dacie JV, Lewis SM. Practical haematology. 6th ed. Edinburgh Churchill Livingstone, 1984.

5 Clark MR, Mohandas N, Embury SH, Lubin BH. A simple labo? ratory alternative to irreversibly sickled cell counts. Blood 1982;60:659-62.

6 Stuart J, Stone PCW, Bareford D, Caldwell NM, Davies JE, Baar S. Evaluation of leucocyte removal methods for studies of erythrocyte deformability. Clin Hemorheol 1985;5:137-47.

7 Hanss M. Erythrocyte filtrability measurement by the initial flow rate method. Biorheology 1983;20:199-211.

8 Lawrence C, Fabry ME, Nagel RL. Red cell distribution width parallels dense red cell disappearance during painful crisis in sickle cell anemia. J Lab Clin Med 1985;105:706-10.

9 Chobanian AV, Lille RD, Tercyak A, Blevins P. The metabolic and hemodynamic effects of prolonged bed rest in normal subjects. Circulation 1974;49:551-9.

10 Self F, McIntire LV, Zanger B. Rheological evaluation of hemoglobin $\mathrm{S}$ and hemoglobin $\mathrm{C}$ hemoglobinopathies. $\mathrm{J}$ Lab Clin Med 1977;89:488-97.

11 Stuart J. Sickle-cell disease and vascular occlusion-rheological aspects. Clin Hemorheol 1984;4:193-207.

12 Ohnishi ST, Horiuchi KY, Horiuchi K. The mechanism of formation of irreversibly sickled cells and modes of action of its inhibitors. Biochim Biophys Acta 1986;886:119-29.

13 Kenny MW, Meakin M, Worthington DJ, Stuart J. Erythrocyte deformability in sickle-cell crisis. $B r J$ Haematol $N$ 1981;49:103-9.

14 Lucas GS, Caldwell NM, Stuart J. Fluctuating deformability of $\omega$ oxygenated sickle erythrocytes in the asymptomatic state and $\underset{<}{ }$ in painful crisis. Br J Haematol 1985;59:363-8.

Requests for reprints to: Dr AJ Keidan, Department of Haematology, The Medical School, University of Birmingham, Birmingham B15 2TJ, England.

(1)

(1)
을 